\title{
Physical and Chemical Changes in Fresh Chilled Muscle Tissue of Common Carp (Cyprinus carpio L.) Packed in a Modified Atmosphere
}

\author{
F. JEŽEK, H. BUCHTOVÁ
}

Department of Meat Hygiene and Technology, Faculty of Veterinary Hygiene and Ecology, University of Veterinary and Pharmaceutical Sciences, Brno, Czech Republic

\author{
Received March 28, 2007 \\ Accepted July 9, 2007
}

\begin{abstract}
Ježek F., H. Buchtová: Physical and Chemical Changes in Fresh Chilled Muscle Tissue of Common Carp (Cyprinus carpio L.) Packed in a Modified Atmosphere. Acta Vet. Brno 2007, 76: S83-S92.

The aim of the study was to monitor the course of physical and chemical changes taking place in stored fresh chilled muscle tissue of carp packed in modified atmosphere (MAP), and to determine its shelf life. Samples of muscle tissue of common carp (Cyprinus carpio, L.) were packed in MAP $\left(80 \% \mathrm{O}_{2}, 20 \% \mathrm{CO}_{2}\right)$ and stored for 15 days at $+2 \pm 2{ }^{\circ} \mathrm{C}$ max. During the storage period, $\mathrm{O}_{2}$ level in packs decreased from $78.7 \pm 0.39 \%$ (day 1 ) to $63.8 \pm 1.30 \%$ (day 15 ). Decrease in $\mathrm{O}_{2}$ in packs between storage days 7 and 9 was highly significant $(p<0.01)$. During storage, muscle tissue $\mathrm{pH}$ decreased during the experiment from $6.46 \pm 0.22 \%$ (day 1 ) to $6.17 \pm 0.10 \%$ (day 15). Levels of $\mathrm{N}$-substances of low-molecular character increased during the experiment from $12.33 \pm 2.11$ (day 1) to $20.07 \pm 3.16 \mathrm{mg} .100 \mathrm{~g}^{-1}$ (day 15). Hydrolytic lipid decomposition (FFA) was more intensive in carp muscle tissue $(2.09 \pm 1.07 \%$ total lipid as oleic acid $)$ than in carp skin $(1.01 \pm 0.31 \%$ total lipid as oleic acid) (day 15). Lipid oxidation (PV) in skin showed differences from lipid oxidation in muscle tissue. Oxidation processes in muscle correlated positively with the length of storage $(\mathrm{r}=0.90)$. Over the storage period, peroxide levels increased from $2.58 \pm 1.19$ mekv O$\cdot \mathrm{kg}^{-1}$ (day 1) to $6.76 \pm 1.78$ mekv O ${ }_{2} \cdot \mathrm{kg}^{-1}$ (day 15). Because of low TVBN levels in muscle tissue, shelf life was limited mainly by sensory changes (green discoloration, odour deviations, slime production), which were observed from storage day 9 onwards. It was found that the maximum shelf life of carp packed in MAP $\left(80 \% \mathrm{O}_{2}, 20 \% \mathrm{CO}_{2}\right)$ was 7 days. The optimum parameter to determine the remaining shelf life of common carp muscle tissue stored at $+2 \pm 2{ }^{\circ} \mathrm{C} \max$ is the TVBN level. As concerns shelf life, TVBN levels in carp muscle should not exceed $15 \mathrm{mg} \cdot 100 \mathrm{~g}^{-1}$. This level of TVBN (max. $15 \mathrm{mg} \cdot 100 \mathrm{~g}^{-1}$ ) for carp (MAP 80\% O, 20\% $\mathrm{CO}_{2}$ ) is much more lower in comparison with levels TVBN ( $\max 25-35 \mathrm{mg} \cdot 100 \mathrm{~g} \mathrm{~g}^{-1}$ ) which have been determined by Commission Regulation (EC) No. 2074/2005 for sea fish. For that reason we suggest to amplify the study by other monitoring (higher number of samples, various breeds of carp in different weight categories for all the year). On the basis of these analyses the level of TVBN for carp could be determined and incorporated to the legislation.
\end{abstract}

Fish, shelf life, $p H$, physical, chemical and sensory changes

Fish is one of foods characterized by poor shelf life $\left(p H>5.2 ; \mathrm{a}_{\mathrm{w}}>0.95\right)$, and they must therefore be stored at chill temperatures $\left(-1\right.$ to $\left.+2{ }^{\circ} \mathrm{C}\right)$. Even under such conditions, shelf life of unpacked fish is very short ( 3 to 5 days), and is limited to a period when the products still meet sensory requirements on freshness categories laid down by the Council Regulation (EC) 2406/1996 and chemical requirements laid down by the Commission Regulation (EC) No. 2074/2005.

In muscle tissue of fresh chilled fish $\left(-1\right.$ to $\left.+2{ }^{\circ} \mathrm{C}\right)$, autolytic and proteolytic changes catalyzed by microbial enzymes take place during storage. Proteins are being gradually cleaved into peptides, amino acids, ammonia and some other low molecular N-substances. Toxic biogenic amines (histamine, tyramine) may be produced by activities of some microorganisms. Shelf life of fat fish is limited by lipid decomposition (Özogul et al. 2005). Oxidation of the fat component may give rise to some mutagens, promoters and 
carcinogens (hydroperoxides, endoperoxides and epoxides of fatty acids and cholesterol, aldehydes, alkoxys and hydroperoxy radicals) (Herzig and Suchý 2006). Sensory quality of products in storage is further impaired by colouring substance oxidation that takes place in fish muscle tissue.

Shelf life of fresh chilled fish can be extended by vacuum packaging or modified atmosphere packaging (MAP). Effects of gases used in packaging have so far been studied mainly in marine fish (Özogul et al. 2000; Davis 1993; Farber 1991). The most frequently used packaging gases include oxygen $\left(\mathrm{O}_{2}\right)$, carbon dioxide $\left(\mathrm{CO}_{2}\right)$, nitrogen $\left(\mathrm{N}_{2}\right)$ and their combinations in different ratios. Gas mixtures with higher levels of $\mathrm{CO}_{2}$ and $\mathrm{N}_{2}$ as inert gases have attracted most attention of researchers. $\mathrm{CO}_{2}$ is very readily soluble in water and fat, and its solubility significantly decreases with decreasing temperatures (Sivertsvik 2002). The most frequently used $\mathrm{CO}_{2}$ concentrations in fish packaging fall between 40 and $60 \% . \mathrm{CO}_{2}$ acts as an antimicrobial agent. It inhibits the growth of spoilage organisms, particularly Shewanella putrefaciens, Pseudomonas, Vibrio and Aeromonas spp. that produce $\mathrm{H}_{2} \mathrm{~S}$ (Jensen et al. 1980; Debevere and Boskou 1996). When applied, it also retards the oxidation reaction. $\mathrm{CO}_{2}$ diffuses to muscle tissue, dissolves in tissue liquids, and carbonic acid is produced there. Statham (1984) mentioned that weak acids in the non-dissociated form were known for their antimicrobial activity, which explains why carbonic acid is specific as microbial inhibitor at neutral $\mathrm{pH}$.

$\mathrm{N}_{2}$ retards the oxidative rancidity and inhibits the growth of aerobic microorganisms by displacing oxygen from packs (Farber 1991; Church 1998). $\mathrm{O}_{2}$ causes the oxidative rancidity of fish fat, promotes the growth of aerobic bacteria and inhibits the growth of strictly anaerobic bacteria (Arashisar et al. 2004; Özogul et al. 2004). $\mathrm{O}_{2}$ is also used as a prevention against the growth of Clostridium botulinum Type E bacteria, which may be found in fish (Ruiz-Capillas and Moral 2001; Özogul F. and Özogul Y. 2006). RuizCapillas and Moral (2001) noted the beneficial effect of higher oxygen concentrations in biochemical analyses. In the $\mathrm{O}_{2}$ environment, the red myoglobin is oxygenated to oxymyoglobin, and long-term storage may cause oxidation of the two pigments to metmyoglobin, which is red-brown to brown in colour (Kropf 1993). Emborg et al. (2005) monitored the effect of psychrotolerant bacteria on the production of histamine in fish packed in modified atmosphere. An important producer of histamine in marine fish is Photobacterium phosphoreum, which is psychrotolerant $\left(0-5{ }^{\circ} \mathrm{C}\right)$ and resistant to $\mathrm{CO}_{2}$ (Dalgaard 2000; Jørgensen et al. 2000; Kanki et al. 2004).

Other gases may also be used for MAP, for instance argon (Ar) or carbon monoxide (CO), which acts to stabilize the red colouring of meat. One of the most important factors affecting the shelf life of fish muscle tissue in MAP is the packing gas to packed product volume ratio. The usually used ratios are $2: 1$ or $3: 1$ (Sivertsvik et al. 2002).

The most common freshwater fish retailed in the Czech Republic are carp and trout. Fish are sold live, fresh chilled unpacked (with shelf life is 2 to 3 days), vacuum packed (with shelf life 5 to 7 days) or frozen. Packing fish in a modified atmosphere is not used by the industry in the Czech Republic, and it has not been subject to experimental monitoring.

The aim of the present study was to monitor the course of physical and chemical changes taking place in stored fresh chilled muscle tissue of carp packed in a modified atmosphere $\left(80 \% \mathrm{O}_{2}, 20 \% \mathrm{CO}_{2}\right)$, and to determine its shelf life.

\section{Materials and Methods}

Carp samples were obtained from Rybníkářství Pohořelice Company, and they were processed at the Mušov freshwater fish processing plant using a standard processing procedure. Fish were first stunned with electric current, killed, scaled, gutted, filleted, cut up and chilled $\left(+2 \pm 2{ }^{\circ} \mathrm{C}\right)$. The samples were then taken to Linde Technoplyn Comp. without any breaks in the cold chain. Here they were packed to the protective sheet Amilen PA/PE 20/60 manufactured by VF Verpackungen $\mathrm{GmbH}$, and filled with a mixture of $80 \% \mathrm{O}_{2}$ and $20 \% \mathrm{CO}_{2}$. The 
sheet was made of polyamide, which is very little permeable to $\mathrm{O}_{2}$, and polyethylene, which is relative permeable to $\mathrm{O}_{2}$. The sheet permeability given by the manufacturer at $23^{\circ} \mathrm{C}^{2}$ is $50 \mathrm{~cm}^{3} \cdot \mathrm{m}^{-2}$ in 24 hours. The packed samples were taken to the cold storage facility of the Institute of Meet Hygiene and Technology at University of Veterinary and Pharmaceutical Sciences in Brno, where they were stored at $+2 \pm 2{ }^{\circ} \mathrm{C}$ max.

A total of 240 samples from 30 carp with mean live weight of $2325.00 \pm 242.81 \mathrm{~g}$ were analyzed. Laboratory analyses were made on storage day $1,3,5,7,9,11,13$ and 15 . Before the samples were unpacked, their oxygen level was determined by a portable Veit Electronics Model 2.00 oximeter. The WTW 340-A/SET-2 digital $\mathrm{pH}$-metre and piercing electrodes applied at the dorsal region were used to measure muscle $\mathrm{pH}$. The total volatile basic nitrogen (TVBN) was determined by direct distillation followed by titration on Tecator Kjeltec using the procedure recommended by the manufacturer (AN 68/83). Free fatty acids (FFA ) were determined in accordance with ČSN ISO 660. Peroxide values (PV) were determined by a modification of the method according to C $\breve{S N}$ ISO 3960. FFA and PV in skin and in muscle were determined independently after fat extraction with diethyl ether. Total muscle tissue fat was determined quantitatively by extraction with solvents on the Soxtec semi-automatic unit (Tecator) using the procedure recommended by the manufacturer (AN 67/83).

Results of the analyses were statistically processed using one-factor ANOVA (Microsoft Office EXCEL 2003).

\section{Results}

Fig. 1 shows $\mathrm{O}_{2}$ levels (\%) in MAP in dependence on the length of the storage period at $+2 \pm 2{ }^{\circ} \mathrm{C} . \mathrm{O}_{2}$ levels in MAP decreased continuously from storage day $1(78.7 \pm 0.39 \%)$ until the end of the experiment. Highly significant $(p<0.01)$ decrease in $\mathrm{O}_{2}$ levels $(\%)$ occurred between storage days $7(76.9 \pm 0.75 \%)$ and $9(67.5 \pm 0.45 \%)$. From day 9 , $\mathrm{O}_{2}$ levels continued to decrease until day $15(63.8 \pm 1.30 \%)$ but the decrease was not statistically significant.

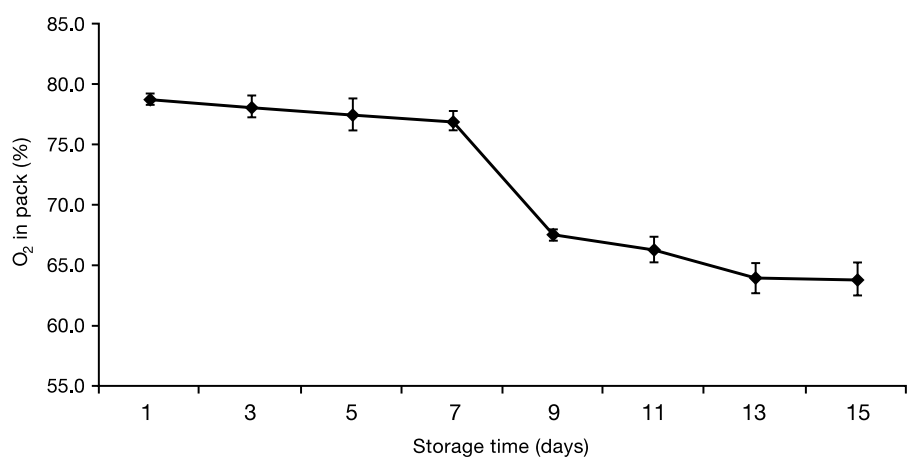

Fig. 1. $\mathrm{O}_{2}$ levels (\%) in MAP in dependence on the length of the storage period at $+2 \pm 2{ }^{\circ} \mathrm{C}$

Fig. 2 shows $\mathrm{pH}$ values in carp muscle tissue in dependence on the length of the storage period at $+2 \pm 2{ }^{\circ} \mathrm{C}$. The values decreased significantly $(p<0.05)$ from storage day $1(6.46 \pm$ $0.22)$ to day $7(6.25 \pm 0.13)$. The increase of $\mathrm{pH}$ on day $9(6.31 \pm 0.12)$ was not statistically significant. From then on, $\mathrm{pH}$ again began to decrease to reach $6.17 \pm 0.10$ on storage day 15 .

Fig. 3 gives TVBN values $\left(\mathrm{mg} \cdot 100 \mathrm{~g} \mathrm{~g}^{-1}\right)$ in carp muscle tissue in dependence on the length of the storage period at $+2 \pm 2{ }^{\circ} \mathrm{C}$. TVBN levels in meat were very low on day $1(12.33$ $\left.\pm 2.11 \mathrm{mg} \cdot 100 \mathrm{~g}^{-1}\right)$. During the experiment, TVBN levels gradually increased to reach the maximum of $20.07 \pm 3.16 \mathrm{mg} \cdot 100 \mathrm{~g}^{-1}$ on day 15. Significant $(p<0.05)$ differences in TVBN concentrations were found between storage days 9 and 11 , and days 13 and 15 .

Checks of fat content in muscle tissue $\left(73.0 \pm 7.2 \mathrm{~g} \cdot \mathrm{kg}^{-1}\right)$ were made to rule out any possibility of hydrolytic (FFA) or oxidative (PV) processes being affected by abnormal (i.e. excessively high or low) levels of fat in muscle tissue. 


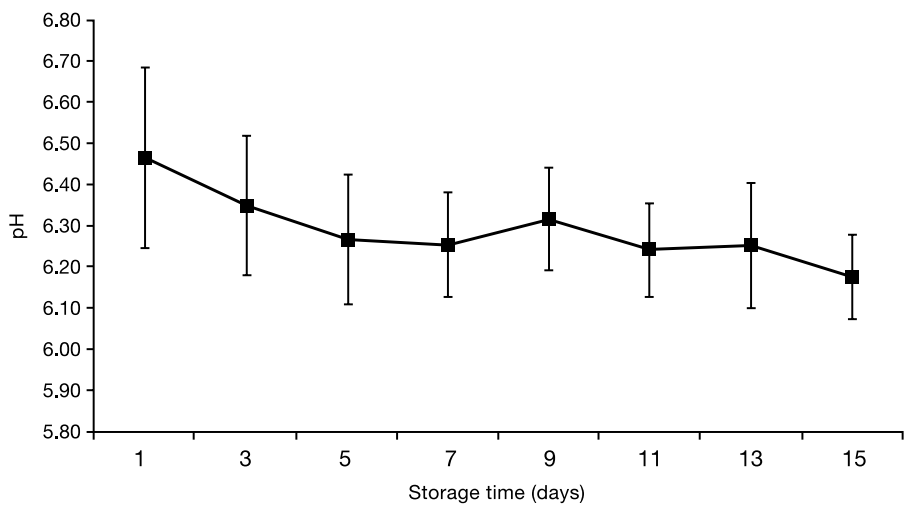

Fig. 2. $\mathrm{pH}$ values in carp muscle tissue in dependence on the length of the storage period at $+2 \pm 2{ }^{\circ} \mathrm{C}$

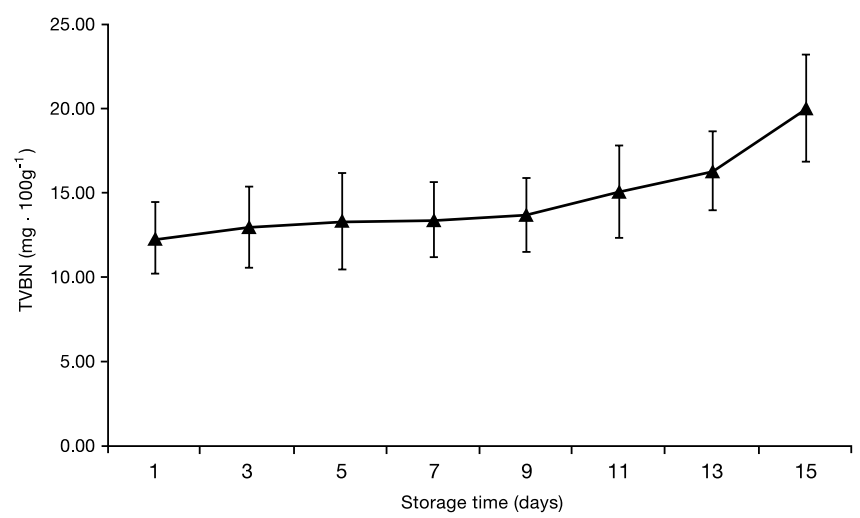

Fig. 3. TVBN values $\left(\mathrm{mg} \cdot 100 \mathrm{~g}^{-1}\right)$ in carp muscle tissue in dependence on the length of the storage period at $+2 \pm 2{ }^{\circ} \mathrm{C}$

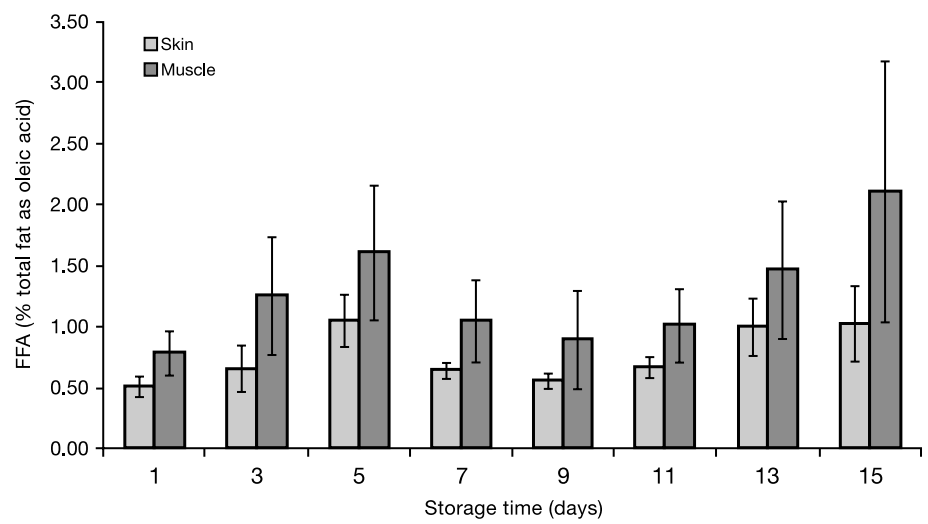

Fig. 4. FFA values (\% total lipid as oleic acid) in carp muscle tissue and skin in dependence on the length of the storage period at $+2 \pm 2{ }^{\circ} \mathrm{C}$

Fig. 4 shows FFA values (\% total lipid as oleic acid) in carp muscle tissue and skin in dependence on the length of the storage period at $+2 \pm 2{ }^{\circ} \mathrm{C}$. FFA levels in muscle fat 
were found consistently higher throughout the experiment. FFA values from carp skin fat varied in dependence on the length of storage period similarly to FFA levels in muscle tissue. On storage day 1, FFA levels in muscle fat and skin fat were low $(0.78 \pm 0.18 \%$ and $0.50 \pm 0.08 \%$ total lipid as oleic acid, respectively). On day 3 (muscle tissue: $1.25 \pm$ $0.48 \%$ total lipid as oleic acid; skin: $0.65 \pm 0.19 \%$ total lipid as oleic acid) and on day 5 (muscle tissue: $1.60 \pm 0.55 \%$ total lipid as oleic acid; skin: $1.04 \pm 0.21 \%$ total lipid as oleic acid), FFA levels in fat showed a highly significant $(p<0.01)$ increase. In the course of further monitoring, a decrease in FFA values was found $(p<0.01)$. From storage day 9 (muscle tissue: $0.88 \pm 0.40 \%$ total lipid as oleic acid; skin: $0.55 \pm 0.06 \%$ total lipid as oleic acid) until storage day 15 (muscle tissue: $2.09 \pm 1.07 \%$ total lipid as oleic acid; skin: $1.01 \pm 0.31 \%$ total lipid as oleic acid), FFA levels increased again highly significantly $(p<0.01)$.

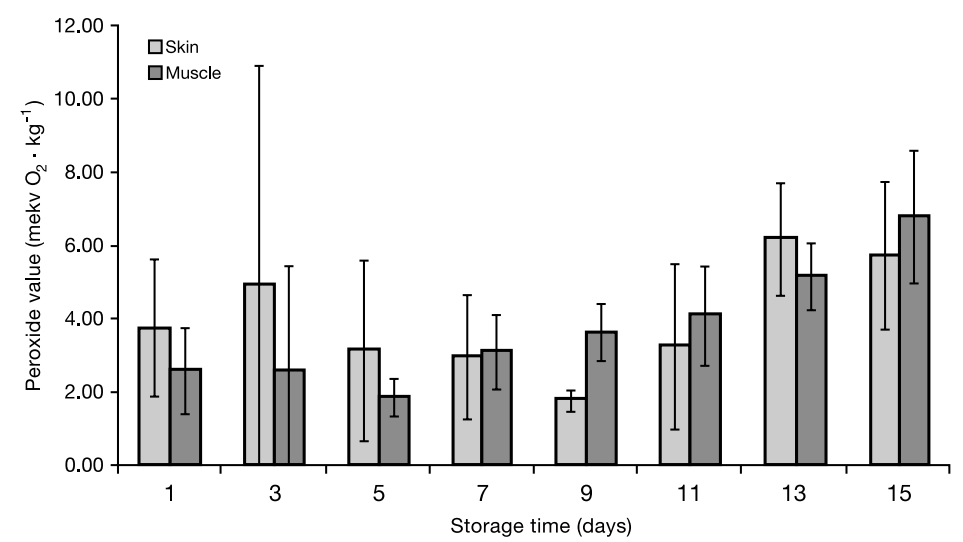

Fig. 5. PV values (mekv $\left.\mathrm{O}_{2} \cdot \mathrm{kg}^{-1}\right)$ in carp muscle tissue and skin in dependence on the length of the storage period at $+2 \pm 2{ }^{\circ} \mathrm{C}$

Fig. 5 shows PV values (mekv $\left.\mathrm{O}_{2} \cdot \mathrm{kg}^{-1}\right)$ in carp muscle tissue and skin in dependence on the length of the storage period at $+2 \pm 2{ }^{\circ} \mathrm{C}$. PV values in muscle tissue fat and skin fat developed differently during the experiment. Until day 7, PV levels were higher in skin fat, but from day 7 until the end of the experiment, higher PV values were found in muscle tissue fat (with the exception of day 13). From storage day $1\left(2.58 \pm 1.19\right.$ mekv $\left.\mathrm{O}_{2} \cdot \mathrm{kg}^{-1}\right)$ there was a statistically non-significant decrease in PV levels in muscle tissue fat $(p>0.05)$ until storage day $5\left(1.86 \pm 0.52 \mathrm{mekv} \mathrm{O}_{2} \cdot \mathrm{kg}^{-1}\right)$. From that day onward, $\mathrm{PV}$ values increased highly significantly $(p<0.01)$ until the end of the experiment to reach $6.76 \pm 1.78 \mathrm{mekv}$ $\mathrm{O}_{2} \cdot \mathrm{kg}^{-1}$ on day 15 . PV values in skin fat showed increase from storage day $1(3.74 \pm 1.88$ mekv $\left.\mathrm{O}_{2} \mathrm{~kg}^{-1}\right)$ until day $3\left(4.92 \pm 5.97 \mathrm{mekv} \mathrm{O}_{2} \cdot \mathrm{kg}^{-1}\right)$. From day 3 until day $9(1.81 \pm 0,29$ mekv $\left.\mathrm{O}_{2} \cdot \mathrm{kg}^{-1}\right)$, PV values decreased $(p<0.01)$. From day 9 , PV values began to again increase highly significantly $(p<0.01)$ to reach $6.18 \pm 1.53 \mathrm{mekv} \mathrm{O}_{2} \cdot \mathrm{kg}^{-1}$ on storage day 13. On day 15 , i.e. the last day of the experiment, $\mathrm{PV}$ values were practically the same ( 5.72 $\left.\pm 2.02 \mathrm{mekv} \mathrm{O}_{2} \cdot \mathrm{kg}^{-1}\right)$.

Fig. 6 (Plate V) shows carp samples placed on a tray and packed in MAP in dependence on the length of the storage period at $+2 \pm 2{ }^{\circ} \mathrm{C}$. The most striking were changes found in the muscle tissue colour. The pink red colouring of samples remained stable until day 7 of the experiment. On day 9 , reduced intensity of pink red colouring of carp muscle was observed together with very slight localized green discoloration of the tissue. These changes grew more prominent as the experiment continued. On 
days 13 and 15, muscle tissue was very light pink in colour with greenish discolouring in spots of various sizes. Changes in other sensory characteristics (odour, presence of slime, consistency) during the experiment were not very prominent. From day 9 onward, odour deviations (musty smell) were noted, which, however, were not typical for fish muscle tissue (trimethyamine). In places of contact between the sample and tray surface, murky slime layer began to form.

Correlation coefficients between individual descriptors monitored in the study are given in Table 1. From the correlations ascertained, the length of storage time acted most significantly to decrease $\mathrm{O}_{2}$ levels in MAP and $\mathrm{pH}$, and increased TVBN and PV levels in muscle tissue.

Table 1. Correlation coefficients between individual descriptors monitored

\begin{tabular}{l|c|c|c|c|c|c|c|}
\hline & Storage time & $\mathrm{pH}$ & TVBN & $\mathrm{FFA}_{\mathrm{s}}$ & $\mathrm{FFA}_{\mathrm{m}}$ & $\mathrm{PV}_{\mathrm{s}}$ & $\mathrm{PV}_{\mathrm{m}}$ \\
\hline $\mathrm{pH}$ & -0.84 & & & & & & \\
\hline TVBN & 0.88 & -0.75 & & & & & \\
\hline FFA $_{\mathrm{s}}$ & 0.53 & -0.67 & 0.63 & & & & \\
\hline $\mathrm{FFA}_{\mathrm{m}}$ & 0.55 & -0.69 & 0.78 & 0.90 & & & \\
\hline $\mathrm{PV}_{\mathrm{s}}$ & 0.37 & -0.25 & 0.61 & 0.57 & 0.64 & & \\
\hline $\mathrm{PV}_{\mathrm{m}}$ & 0.90 & -0.64 & 0.95 & 0.42 & 0.58 & 0.58 & \\
\hline Oxygen & -0.94 & 0.64 & -0.80 & -0.37 & -0.37 & -0.33 & -0.87 \\
\hline
\end{tabular}
s- skin, ${ }_{\mathrm{m}}^{- \text {muscle }}$

\section{Discussion}

The food industry comes up with more and more applications for modified atmosphere packaging (MAP). Modified composition of atmosphere helps extend the keeping quality of foods, and it enhances their quality and safety. In the Czech Republic, MAP is mainly used for meat products $\left(30 \% \mathrm{CO}_{2}, 70 \% \mathrm{~N}_{2}\right)$ and fresh red meat $\left(80 \% \mathrm{O}_{2}, 20 \% \mathrm{CO}_{2}\right)$. Modified atmosphere used in some countries (Japan, Norway, USA) for packing fish consists of $1 \%$ $\mathrm{CO}, 30 \% \mathrm{CO}_{2}, 5 \% \mathrm{O}_{2}$ and $64 \% \mathrm{~N}_{2}$ (John 2005; Eilert 2005). The use of carbon monoxide in the EU is not allowed. For that reason, authors of this study experimented with carp muscle samples packed in modified atmosphere that is used for red meat (beef, pork) in the Czech Republic.

Atmosphere with a large percentage of $\mathrm{O}_{2}(80 \%)$ causes oxygenation of heme pigments present in meat, when the oxygen molecule binds to the central iron atom. The formation of deep-red oxymyoglobin stabilizes the naturally red colouring of meat. From the colour stability point of view, partial pressure of gases in MAP should be maintained as long as possible. Their levels are influenced especially by barrier properties of the packaging sheet and biochemical processes in muscle tissue that determine keeping quality of meat and its colouring.

In our experiment, too, we observed pink red colouring of muscle tissue, which is not typical for carp muscle, and occurred as a result of oxymyoglobin formation. This colouring remained stable until day 7 of the experiment. On day 9, highly significant $(p<0.01)$ drop in partial pressure of $\mathrm{O}_{2}$ was observed that demonstrated itself by reduced intensity of pink red colouring of carp muscle tissue and slight green discolouration in places. These changes grew more prominent as the experiment continued. At the end of the experiment (storage day 15), muscle tissue was very light in colour (white pink) with greenish foci of various sizes (Fig. 6). They were probably the result of myoglobin oxidation, or, rather, its auto-oxidation. As the $\mathrm{O}_{2}$ pressure in MAP and muscle $\mathrm{pH}$ decreased towards the end of the experiment, oxidation processes were accelerated. The 
continued metmyoglobin oxidation caused the formation of green pigments (choleglobin, verdoglobin and verdoheme) (Fig. 1).

Fish generally contain very little glycogen $(0.3 \%)$. The production of lactic acid is restricted, which affects changes in $\mathrm{pH}$. In our experiment, we found very slight acidification of muscle tissue from $\mathrm{pH} 6.46 \pm 0.22 \%$ (day 1) to $\mathrm{pH} 6.17 \pm 0.10 \%$ (day 15). A number of authors (Ruiz-Capillas and Moral 2001; Debevere and Boskou 1996; Statham 1984 and Banks et al. 1980) believe that $\mathrm{CO}_{2}$ diffusion to muscle tissue and the parallel formation of carbonic acid also play a role in $\mathrm{pH}$ reduction. In atmosphere that he used to pack fish in $\left(50 \% \mathrm{O}_{2}, 50 \% \mathrm{CO}_{2}\right)$, Stenström (1985) found microflora (44\% Lactobacillus spp., 38\% Shewanella putrefaciens and 10\% Brochothrix thermosphacta) whose acid products also decreased muscle $\mathrm{pH}$. Muscle $\mathrm{pH}$ of carp in our experiment may have also been influenced by the formation of carbonic acid and by microbial products. The statistically non-significant $\mathrm{pH}$ increase on day 9 may have been caused by the conversion of lactic acid to $\mathrm{CO}_{2}$ and water. The fact that changes in $\mathrm{pH}$ values during the experiment were not statistically significant makes this parameter unsuitable for keeping quality assessments for carp packed in modified atmosphere. In spite of that, however, Huss (1995) used $\mathrm{pH} 7$ as the uppermost acceptable limit for fish. Based on $\mathrm{pH}$ monitoring during storage, $\mathrm{pH} 6.8$ was established as the maximum permitted $\mathrm{pH}$ for stored fish in Brazil (Scherer et al. 2006) (Fig. 2).

TVBN levels were monitored as the main parameter of fish muscle freshness. TVBN are produced by decomposition of proteins into simpler substances (ammonia, trimethylamin, creatine, purine bases, free amino acids). Scherer et al. (2006) noted that TVBN levels were more suitable for spoilage assessment in marine than in freshwater fish. For certain marine fish species important for the food business, TVBN limit values have been laid down in legislation (Commission Regulation (EC) No. 2074/2005). The fish species include Sebastes spp., Salmo salar, and species of the families Pleuronectidae, Merlucciidae, Gadidae, and the relevant TVBN limit values range from 25 to $35 \mathrm{mg} \cdot 100 \mathrm{~g} \mathrm{~g}^{-1}$. No statutory TVBN limit values have been laid down for freshwater fish. In our experiment, TVBN levels in carp after 15 days of storage were lower $(20.07 \pm 3.16$ $\mathrm{mg} \cdot 100 \mathrm{~g}^{-1}$ ) than the limits laid down by Commission Regulation (EC) No. 2074/2005 for marine fish. In view of sensory changes that we observed in the carp, the TVBN limit value that we propose is that ascertained at storage day 7 . The maximum acceptable TVBN value for the rainbow trout (Oncorhynchus mykiss) mentioned in some studies is $25 \mathrm{mg} \cdot 100 \mathrm{~g}^{-1}$ (Arashisar et al. 2004). According to Debevere and Boskou (1996), greater $\mathrm{O}_{2}$ availability in the atmosphere caused lower trimethylaminoxide (TMAO) utilization as the secondary electron acceptor, which resulted in reduced production of trimethylamine (TMA) as a component of fishy smell and TVBN (Fig. 3).

The course of hydrolytic processes in muscle tissue and skin were monitored on the basis of FFA levels determination. According to Özogul et al. (2005), FFA interacting with myofibrillar proteins negatively affect muscle texture. In our experiment, we repeatedly found higher hydrolytic activity in muscle than in skin. Presence of FFA in freshwater fish fat is not regulated from the safety point of view in legislation. The fact that FFA values fluctuated during the experiment makes this parameter unsuitable for assessments of keeping quality of carp packed in a modified atmosphere (Fig. 4).

The oxidation of fats present in food may produce substances harmful to health (mutagens, promoters and carcinogens). The makes the use of MAP with high $\mathrm{O}_{2}$ levels very questionable. Gimenez et al. (2002) recorded more intensive oxidation of fats in a modified atmosphere with 20 and $30 \% \mathrm{O}_{2}$ than in an atmosphere with only $10 \%$ $\mathrm{O}_{2}$. Jayasingh et al. (2002) also found higher oxidation of samples in MAP with $80 \%$ $\mathrm{O}_{2}$ than in the controls exposed to the ambient air. According to Ruiz-Capillas and Moral (2001), lipid oxidation depends on the synergy effect between $\mathrm{CO}_{2}$ and $\mathrm{O}_{2}$. 
For that reason, oxidation taking place in an atmosphere with $40 \% \mathrm{O}$, may be more intensive than in an atmosphere with $60 \% \mathrm{O}_{2}$. They found no significant differences in lipid oxidation during storage in most of the atmospheres analyzed. The course of oxidation changes was not unambiguous in our experiment, either. That makes PV values unsuitable as a criterion for assessments of shelf life of carp packed in modified atmosphere. To assess the degree of oxidation, it would be more appropriate to monitor changes in lipid oxidation based on malondialdehyde levels as the product of secondary oxidation (Özogul et al. 2005; Arashisar et al. 2004). No such analysis was, however, made in our experiment (Fig. 5).

Our study showed that the most suitable parameter for the assessment of shelf life of common carp muscle packed in modified atmosphere is the TVBN level. In view of proven sensory changes, we propose $15 \mathrm{mg} \cdot 100 \mathrm{~g}^{-1}$ TVBN as the maximum limit value for carp muscle. According to Masniyom et al. (2002), TVBN levels in fresh good quality fish are below $12 \mathrm{mg} \cdot 100 \mathrm{~g}^{-1}$. On the basis of our study, we cannot recommend the use of FFA or PV levels for the fish muscle freshness assessment. Ruiz-Capillas and Moral (2001) and Fey and Ragenstein (1982) also concluded that oxidation level monitoring of fish muscle packed in MAP is of no major importance. Based on the results ascertained, in view of sensory changes, shelf life of the common carp packed in MAP $\left(80 \% \mathrm{O}_{2}, 20 \% \mathrm{CO}_{2}\right)$ was therefore set at 7 days.

\section{Fyzikálně chemické změny čerstvé chlazené svaloviny kapra obecného (Cyprinus carpio L.) balené do modifikované atmosféry}

Cílem práce bylo sledovat průběh fyzikálně chemických změn, ke kterým dochází v průběhu skladování v čerstvé chlazené svalovině kapra baleného do modifikované atmosféry a stanovit dobu její údržnosti. Vzorky svaloviny kapra obecného (Cyprinus carpio, L.) byly zabaleny do MAP $\left(80 \% \mathrm{O}_{2}, 20 \% \mathrm{CO}_{2}\right)$ a skladovány při teplotě max. $+2 \pm 2{ }^{\circ} \mathrm{C}$ po dobu 15 dnů. V průběhu skladování došlo ke snížení obsahu $\mathrm{O}_{2} \mathrm{v}$ balení z hodnoty $78.7 \pm 0.39 \%$ (1. den) až na hodnotu $63.8 \pm 1.30 \%$ (15. den). Mezi 7. a 9. dnem skladování byl pokles obsahu $\mathrm{O}_{2}$ v balení vysoce průkazný $(p<0.01)$. Hodnota $\mathrm{pH}$ svaloviny se během experimentu postupně snižovala z $6.46 \pm 0.22$ (1. den) na 6.17 \pm 0.10 (15. den). Obsah N-látek nízkomolekulární povahy se v průběhu experimentu zvyšoval z hodnoty $12.33 \pm 2.11$ (1. den) na hodnotu $20.07 \pm 3.16 \mathrm{mg} \cdot 100 \mathrm{~g}^{-1}$ (15. den). Průběh hydrolytického rozkladu tuků (FFA) probíhal u kapra intenzivněji ve svalovině $(2.09 \pm 1.07 \%$ total lipid as oleic acid $)$ než v kůži $(1.01 \pm 0.31 \%$ total lipid as oleic acid) (15. den). Oxidace tuků (PV) probíhala v kủži a ve svalovině rozdílně. Oxidační procesy ve svalovině pozitivně korelovaly s dobou skladování $(\mathrm{r}=0.90)$, kdy se obsah peroxidů zvýšil z $2.58 \pm 1.19$ mekv $\mathrm{O}_{2} \cdot \mathrm{kg}^{-1}$ (1. den) na $6.76 \pm 1.78$ mekv $\mathrm{O}_{2} \cdot \mathrm{kg}^{-1}(15$. den). Vzhledem k nízkým hodnotám obsahu TVBN ve svalovině limitovaly údržnost především senzorické změny (zelené diskolorace, pachové odchylky, tvorba hlenu), které byly zjišt'ovány od 9. dne skladování. Doba údržnosti kapra baleného do MAP $\left(80 \% \mathrm{O}_{2}, 20 \% \mathrm{CO}_{2}\right)$ byla stanovena na max. 7 dnů. Pro kontrolu údržnosti svaloviny kapra obecného skladovaného při teplotě max. $+2 \pm 2{ }^{\circ} \mathrm{C}$ se jako nejvhodnější jeví stanovení obsahu TVBN. Jejich obsah ve svalovině kapra by z hlediska údržnosti neměl být vyšší než $15 \mathrm{mg} \cdot 100 \mathrm{~g}^{-1}$. Tato hodnota TVBN (max. $15 \mathrm{mg} .100 \mathrm{~g}^{-1}$ ) pro kapra (MAP $\left.80 \% \mathrm{O}_{2}, 20 \% \mathrm{CO}_{2}\right)$ je však ve srovnání s hodnotami TVBN (max $\left.25-35 \mathrm{mg} \cdot 100 \mathrm{~g}^{-1}\right)$ stanovenými (Nařízení Komise ES 2074/2005) pro mořské ryby výrazně nižší. Z tohoto důvodu doporučujeme experiment rozšíritit o další sledování (zvýšit počet vzorků, sledovat různá plemena kaprů různých hmotnostních kategorií v průběhu celého roku) a závaznou hodnotu TVBN pro kapra, která by mohla být začleněna do legislativy, stanovit až na základě těchto dalších analýz. 


\section{Acknowledgement}

This experimental study was supported by the Ministry of Education, Youth and Sports of the Czech Republic (Research Plan MSM6215712402).

The authors are also grateful to all the staff of Rybnikářství Pohořelice Comp. for their kind help in processing the fish and their overall technical assistance.

\section{References}

ARASHISAR Ş, HISAR O, KAYA M, YANIK T 2004: Effect of modified atmosphere and vacuum packaging on microbiological and chemical properties of rainbow trout (Oncorhynchus mykiss) fillets. Int $\mathrm{J}$ Food Microbiol 97: 209-214

BANKS H, NICKELSON II R, FINNE G 1980: Shelf-life studies on carbon dioxide packaged finfish from the gulf of Mexico. J Food Sci 45: 157-162

CHURCH N 1998: MAP fish and crustaceans-sensory enhancement. Food Sci Technol Today 12: 73-83

DALGAARD P 2000: Fresh and lightly preserved seafood. In: MAN CMD, JONES AA (Eds.), Shelf life Evaluation of Foods. Aspen Publisher, Inc., London, pp. 110-139

DAVIS HK 1993: Modified atmosphere packing of fish. In: PARRY RT, Principles and applications of modified atmosphere packaging of foods. Blackie Academic and Professional, London, pp. 189-228

DEBEVERE J, BOSKOU G 1996: Effect of modified atmosphere packaging on the TVB/TMA-producing microflora of cod fillets. Int J Food Microbiol 31: 221-229

EILERT SJ 2005: New packaging technologies for the 21 ${ }^{\text {st }}$ century. Meat Sci 71: 122-127

EMBORG J, LAURSEN BG, DALGAARD P 2005: Significant histamine formation in tuna (Thunnus albacares) at $2{ }^{\circ} \mathrm{C}$ - effect of vacuum- and modified atmosphere-packaging on psychrotolerant bacteria. Int J Food Microbiol 101: 263-279

FARBER JM 1991: Microbiological aspects of modified-atmosphere packing technology - a review. J Food Sci 9: 58-70

FEY MS, RAGENSTEIN JM 1982: Extending shelf-life of fresh wet red hake and salmon using $\mathrm{CO}_{2}-\mathrm{O}_{2}$ modified atmosphere and potassium sorbate ice at $1{ }^{\circ} \mathrm{C}$. J Food Sci 47: 1048-1054

GIMENEZ B, RONCALES P, BELTRAN JA 2002: Modified atmosphere packaging of filleted rainbow trout. J Sci Food Agri 82: 1154-1159

HERZIG I, SUCHÝ P 2006: Harmful and toxic stuffs in fodder of animal origin (In Czech). Institute of Animal Science, Prague, http://www.vuzv.cz/vyziva/studie13.doc, accessed on January 26, 2007

HUSS HH: Quality and quality changes in fresh fish. FAO Fisheries Technical Paper - 348. Food and Agriculture Organization of the United Nations, Rome 1998, 202 p.

JAYASINGH P, CORNFORTH DP, BRENNAND CP, CARPENTER CE, WHITTIER DR 2002: Sensory evaluation of ground beef stored high-oxygen modified atmosphere packaging. J Food Sci 9: 3493-3496

JENSEN MH, PETERSEN A, RØGE EH, JEPSEN A, 1980: Chilled and frozen storage. Storage of chilled cod under vacuum and at various concentrations of carbon dioxide. In: J. J. Conell and staff of Torry Research Station (editors), Advances in Fish and Technology, Fishing News Books, London: pp. 294-297

JOHN L, CORNFORTH D, CARPENTER CE, SORHEIM O, PETTEE BC, WHITTIER DR 2005: Colour and thiobarbituric acid values of cooked top sirloin steaks packaged in modified atmospheres of $80 \%$ oxygen, or 0.4\% carbon monooxide or vacuum. Meat Sci 69: 441-449

JØRGENSEN LV, HUSS HH, DALGAARD P 2000: The effect of biogenic amine production by single bacterial cultures and metabiosis on cold-smoked salmon. J Appl Microbiol 89: 920-934

KANKI M, YODA T, ISHIBASHI M, TSUKAMOTO T 2004: Photobacterium phosphoreum cause a histamine fish poisoning incident. Int J Food Microbiol 92: 79-87

KROPF DH 1993: Color stability: factors affecting the color of fresh meat. Meat Focus Intern 1: 269-275

MASNIYOM P, BENJAKUL S, VISESSANGUAN W 2002: Shelf-life extension of refrigerated seabass sloves under modified atmosphere packaging. J Sci Food Agri 82: 873-880

ÖZOGUL F, ÖZOGUL Y 2006: Biogenic amine content and biogenic amine quality indices of sardines (Sardina pilchardus) stored in modified atmosphere packaging and vacuum packaging. Food Chem 99: 574-578

ÖZOGUL F, POLAT A, ÖZOGUL Y 2004: The effect of modified atmosphere packaging and vacuum packaging on chemical, sensory and microbiological changes of sardines (Sardina pilchardus). Food Chem 85: 49-57

ÖZOGUL F, TAYLOR KDA, QUANTICK P, ÖZOGUL Y 2000: Chemical, microbiological, and sensory evaluation of Atlantic herring (Clupea harengus) stored in ice, modified atmosphere and vacuum pack. Food Chem 71: 267-273

ÖZOGUL Y, ÖZYURT G, ÖZOGUL F, KULEY E, POLAT A 2005: Freshness assesment of European eel (Anguilla anguilla) by sensory, chemical and microbiological methods. Food Chem 92: 745-751

RUIZ-CAPILLAS C, MORAL A 2001: Chilled bulk storage of gutted hake (Merluccius merluccius, L.) in CO, and $\mathrm{O}_{2}$ enriched controlled atmospheres. Food Chem 74: 317-325

SCHERER R, AUGUSTI PR, BOCHI VC, STEFFENS C, FRIES LLM, DANIEL AP, KUBOTA EH, NETO JR, EMANUELLI T 2006: Chemical and microbiological quality of grass carp (Ctenopharyngodon idella) slaughtered by different methods. Food Chem 99: 136-142 
SIVERTSVIK M, JEKSRUD WK, ROSNES JT 2002: A review of modified atmosphere packaging of fish and fishery products - significance of microbial growth, activities and safety. Int J Food Sci Tech 37: 107-127

STATHAM JA 1984: Modified atmosphere storage of fisheries products: the state of the art. Food Tech Austr 36: $233-239$

STENSTRÖM IJ, 1985: Microbial flora of cod fillets (Gadus morhua) stored at $2{ }^{\circ} \mathrm{C}$ in different mixtures of carbon dioxide and nitrogen/oxygen. J Food Protect 48: 585-589 
Plate V

Ježek F. et al.: Physical and Chemical ... pp. S83-S92

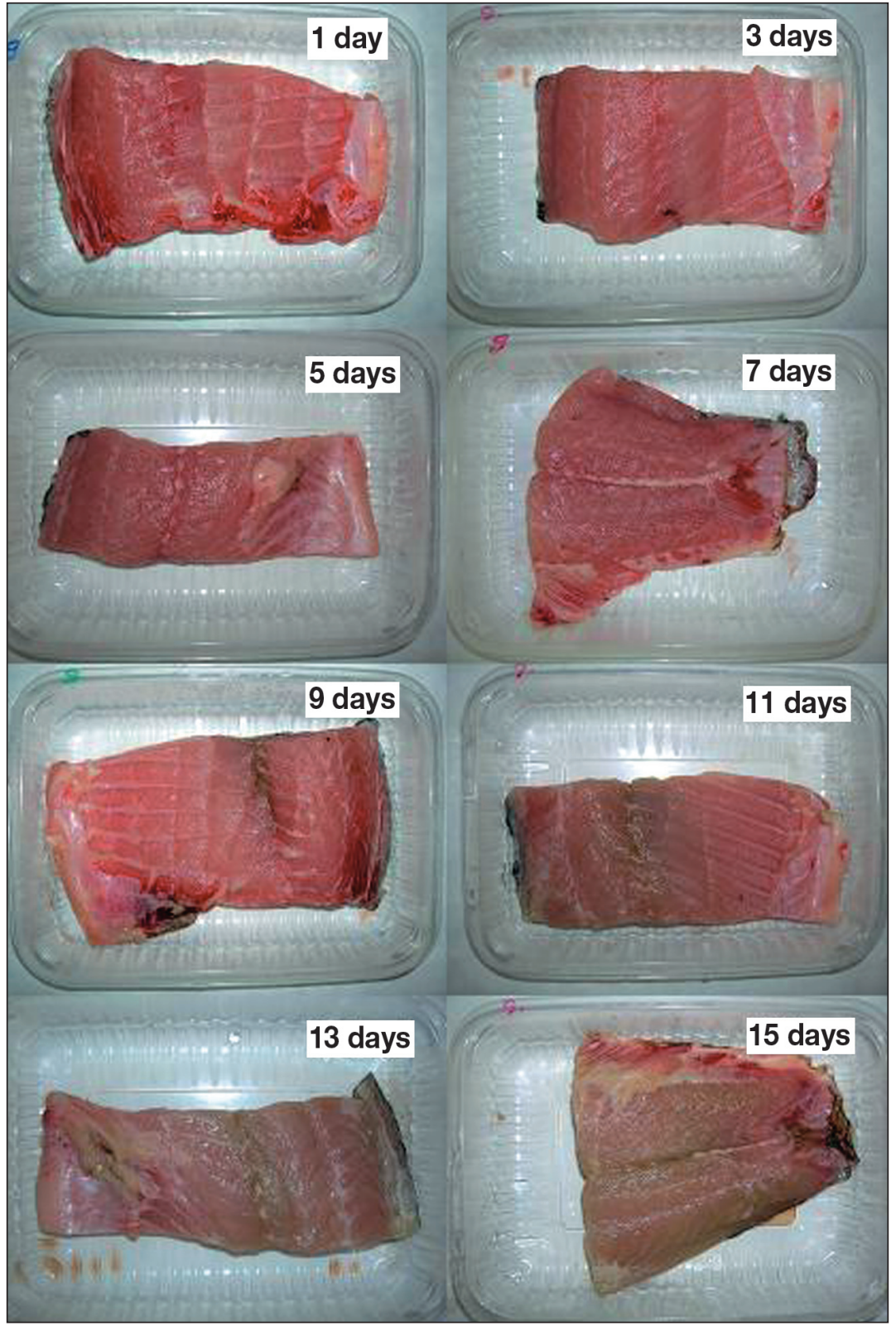

Fig. 6. Carp samples placed on a tray and packed in MAP in dependence on the length of the storage period at $+2 \pm 2{ }^{\circ} \mathrm{C}$ 